\title{
PERAN GURU DAN ORANG TUM MEMBENTUK KARAKTER JUJUR PADA ANAK
}

\author{
Nikmah Rochmawati \\ UIN Walisongo Semarang \\ nikmahrahmawati@yahoo.com atau rahma_mewangi@walisongo.ac.id
}

\begin{abstract}
This paper is motivated by there are some dishonesty in the community, such as hoax news, hate speech, prejudice, cheating, corruption, theft, fraud, robbery that cause anxiety, mutual suspicion and disharmony in social life. Why does this happen? Because teachers at school and parents at home can not build honest characters to their children. Therefore, this writing will describe how teachers and parents form an honest character in children. Stages of character formation will be correlated with psychological theory. The results of the study found that to educate an honest character, children are not only given cognitive knowledge about honesty, but also must touch the level of affection domain and implemented in real behavior.
\end{abstract}

Keywords: teachers role; parents role; character; honest.

\section{Abstrak}

Tulisan ini dilatarbelakangi oleh adanya ketidak jujuran yang mewabah di masyarakat yaitu banyak sekali muncul berita hoax, ujaran kebencian, prasangka, mencontek, korupsi, pencurian, penipuan, perampokan sehingga berdampak pada keresahan, saling curiga dan ketidak harmonisan dalam hidup bermasyarakat. Mengapa hal ini bisa terjadi? Karena pembentukan karakter jujur pada anak tidak berhasil oleh guru di sekolah dan orang tua di rumah. Karena itulah, tulisan inilah yang akan mendeskripsikan bagaimana cara guru dan orang tua membentuk karakter jujur pada anak. Tahapan-tahapan pembentukan karakter akan dikorelasikan dengan teori psikologi. Hasil kajian menemukan bahwa untuk membentuk karakter jujur, anak tidak hanya dibekali pengetahuan kognitif tentang kejujuran, tapi juga harus sampai pada ranah afektif dan terimplementasi dalam perilaku nyata.

Kata kunci: peran guru; orang tua; karakter; jujur; 


\section{A. PENDAHULUAN}

Pendidikan merupakan tonggak peradaban, pembentuk karakter dan kepribadian serta merupakan salah satu kebutuhan primer manusia untuk mengembangkan keunikan dan potensi yang dimilikinya. Baik itu pendidikan formal maupun non formal, pendidikan di sekolah maupun di rumah. Hal yang paling urgen dalam pendidikan informal adalah pendidikan dalam keluarga. Keluarga merupakan tempat pertamakali anak memperoleh pendidikan dan merupakan pondasi dasar bagi terbentuknya karakter dan kepribadian. Oleh karena itu, orang tua hendaknya mampu mendidik anak-anaknya(Al-Akk, 2006) dan dapat menjadi role model yang baik.

Driyarkara menjelaskan bahwa orang pertama yang harus menjadi pendidik adalah orang tua. Orang tua bertanggung jawab mendidik anak-anaknya agar berkembang menjadi manusia dewasa yang utuh (Suparno, 200I). Oleh karena itu, pendidikan yang dilakukan orang tua terhadap anak sangat penting, karena kedua orang tua adalah manusia yang paling dekat dengan anak.

Anak akan diarahkan baik atau jahat tergantung pada orang tua. Ketika orang tua baik, anak akan menjadi baik, dan sebaliknya, ketika orang tua tidak baik, anak juga akan kurang baik. Namun demikian, tidak hanya orang tua yang mempunyai kewajiban terhadap pendidikan seorang anak, tetapi juga lingkungan dan masyarakat yang ada di sekitarnya juga mempunyai tanggung jawab sosial dan moral untuk membentuk karakter seorang anak yang sesuai dengan harapan sosial.

Selain itu, institusi pendidikan tentu adalah pihak yang sangat penting setelah orang tua untuk membentuk karakter anak yang baik dan mampu memberikan nafas pendidikan dalam kehidupan sehari-harinya. Karena memang anak juga banyak menghabiskan waktunya di dalam institusi sekolah atau pendidikan. Karena itu, tidak salah kiranya jika kita berbicara institusi pendidikan berarti juga berbicara mengenai kehidupan, karena pendidikan merupakan proses yang dilakukan setiap individu menuju ke arah yang lebih baik sesuai dengan potensi kemanusiaannya.

Pendidikan berarti memasukkan anak ke alam nilai-nilai, juga memasukkan dunia nilai ke dalam jiwa anak. Pendidikan di sini, sebagai suatu bentuk hidup bersama, berarti pemasukan manusia muda ke alam nilainilai dan kesatuan antarpribadi yang mempribadikan. Mendidik adalah pertolongan atau pengaruh yang diberikan orang yang bertanggung jawab kepada anak agar mereka menjadi dewasa (Driyarkara, 1980).

Selain itu, pendidikan tidak hanya terpaku pada transfer materi dari guru ke murid. Pendidikan harus utuh dan menyeluruh, meliputi semua aspek dalam kehidupan manusia. Pendidikan harus berorientasi pada terbentuknya individu-individu yang memiliki karakter atau jati diri (kepribadian) yang syamil (lengkap, utuh, menyeluruh).

Tidak seperti halnya yang terjadi pada saat sekarang ini, di mana manusia sudah kehilangan karakternya sebagai insan yang beradab dan berbudaya. Hal ini bisa kita lihat dari banyaknya berbagai tindakan negatif-destruktif yang dilakukan oleh insan-insan pendidikan kita. Mulai dari tawuran antar pelajar, demonstrasi mahasiswa yang berujung pada tindakan anarkis, maraknya tindakan asusila yang dilakukan para insan pendidikan kita, hingga pada membudayanya praktik korupsi yang dilakukan oleh insan sangat terdidik kita. Hal ini terjadi karena karakter yang baik sudah hilang atau tergerus oleh lingkungan dan peradaban yang semakin permisif. Hal ini bermula dari ketidakjujuran segala komponen bangsa ini terhadap kondisi yang ada, bahwa ada hal yang salah dalam pola pendidikan di negeri ini.

Dunia pendidikan yang seharusnya menjadi barikade yang kokoh untuk membentengi para insan pelajar dan kaum terpelajar dari gerusan aksi negatif seperti itu dinilai telah mengalami kemandulan. Pendidikan tidak diarahkan untuk "memanusiakan manusia” secara utuh dan paripurna, tetapi lebih diorientasikan untuk mempertahankan jargon dan kepentingan kekuasaan semata. Selama mengikuti proses pendidikan, anak-anak bangsa negeri ini hanya sekadar menjadi objek ilmu pengetahuan yang serba pendiam dan penurut, sehingga kehilangan daya kreatif dan sikap kritis. Padahal menurut Driyarkara, inti pendidikan adalah pemanusiaan manusia muda.

Pada dasarnya pendidikan adalah pengembangan 
manusia muda ke taraf insani (Driyarkara, I980). Sedangkan Ki Hajar Dewantara menyatakan bahwa pendidikan merupakan tuntutan bagi pertumbuhan anak-anak. Artinya, pendidikan menuntut segala kekuatan kodrat yang ada pada diri anak-anak, agar mereka sebagai manusia sekaligus sebagai anggota masyarakat dapat mencapai keselamatan dan kebahagiaan setinggi-tingginya (Dewantara, I977).

Pendidikan karakter atau akhlak merupakan aspek pendidikan tersulit dalam dunia pendidikan secara umum. Hal itu karena pendidikan akhlak merupakan bagian dari pendidikan jiwa yang tidak dapat langsung dilihat oleh kasat mata seperti halnya pendidikan fisik. Walaupun pendidikan karakter merupakan pendidikan yang sangat sulit, tetapi pembentukan karakter merupakan hal yang sangat urgen dan tidak dapat diabaikan, karena karakter berkaitan erat dengan kebahagiaan dan kesuksesan seseorang.

Oleh karena itu,wajib bagi para guru di sekolah dan orang tua di rumah untuk mendisik siswa dan putraputrinya agar menjadi insan yang cerdas dan berakhlak mulia (Al-'Akk, 2006). Oleh karena itu, bagaimana pun kita harus terus memberikan pendidikan akhlak kepada anak didik generasi bangsa, meskipun akan mengalami kendala yang cukup kompleks mengingat mendidik akhlak berarti mendidik jiwa. Sedangkan jiwa adalah sesuatu yang tidak bisa diukur dengan pasti gerak dan arahnya. Yang bisa dilakukan dalam hal ini adalah bagaimana memaksimalkan potensi jiwa tersebut agar selalu diarahkan kepada potensi yang positif dan meminimalkan gerak jiwa yang mengarah kepada halhal yang negatif.

Salah satu karakter dan akhlak yang baik adalah kejujuran. Kejujuran ini sangatlah mahal harganya saat ini. Praktik mencontek berawal dari sikap tidak jujur siswa. Mencuri dan melakukan hal-hal yang tidak terpuji lainnya, juga berawal dari ketidakjujuran terhadap dirinya sendiri dan terlebih lagi terhadap orang lain. Bahkan korupsi juga berawal dari ketidakjujuran pelakunya. Hal itu semua adalah karakter tidak baik yang dipertontonkan oleh insan-insan pendidikan di Indonesia.

Dari sini, hal yang menjadi persoalan adalah sampai sejauh manakah pendidikan mampu memberikan pengaruh yang signifikan dalam menanamkan karakter jujur dalam kehidupan anak? Lalu bagaimanakah peran dunia pendidikan dan orangtua dalam penanaman kejujuran anak didik? Hal inilah yang akan dibahas dalam tulisan ini.

Tujuannya adalah agar bisa diketahui secara jelas bagaimana peran pendidikan dalam menanamkan karakter yang baik. Selain itu, juga bisa diketahui dengan baik bagaimana peran orangtua dan guru dalam menanamkan kejujuran pada diri anak didik. Hal ini berguna bagi penyiapan masa depan generasi penerus bangsa yang berkarakter dan jujur terhadap apa yang dilakukannya sehingga akan membawa bangsa ini kepada bangsa yang bermartabat, berkarakter, dan maju serta berperadaban yang baik.

\section{B. KAJIAN TEORI PEMBELAJARAN DAN PERKEMBANGAN ANAK}

Ada beberapa teori pembelajaran dan perkembangan anak yang sangat penting untuk diketahui dalam melihat peran orangtua dan guru dalam proses pendidikan ini.

\section{I.Teori Perkembangan Moral Lawrence Kohlberg}

Pada dasarnya, yang termasuk ke dalam kelompok usia dini adalah kelompok usia 4-6 tahun yaitu usia sekolah Taman Kanak-Kanak Kelompok A dan Kelompok B. Karena itulah, menurut Lawrence Kohlberg, usia kemampuan penalaran moral anak usia 4-6 tahun adalah berada pada tahap penalaran moral pra-konvensional. Usia penalaran Pra Konvensional dibagi menjadi dua tahap, yaitu (Slavin, 2009): (I) tahap pertama adalah tahap orientasi hukum dan ketaatan (the punishment-obiedience level).

Nalar anak dalam melakukan sesuatu tentang baik dan buruk adalah berdasarkan rewards dan punishment yang dia terima. Konsekuensi fisik tindakan menentukan kebaikan dan keburukannya. (2) tahap kedua adalah tahap orientasi relativis instrumental. Apa yang benar adalah apa saja yang memuaskan kebutuhan diri sendiri dan kadang-kadang kebutuhan orang lain. Ada unsur-unsur keadilan dan ketimbalbalikan di sini, seperti: Kamu mencoret-coret buku saya, maka saya balas mencoret-coret bukumu. Balas dendam itu termasuk tahapan moral ini. 


\section{Teori Pengondisian Operan BF. Skinner}

Setiap makhluk hidup pasti selalu berada dalam proses melakukan sesuatu terhadap lingkungannya, yang dalam artian sehari-hari berarti dia hidup di dalam dunia, yang melakukan apa yang dituntut oleh hakikat alamiah dirinya. Selama melakukan proses "operasi” ini, makhluk hidup tersebut pasti menerima stimulan-stimulan tertentu yang disebut stimulan yang menggugah. Stimulan-stimulan ini berdampak pada meningkatnya proses cara kerja tadi, yaitu perilakuperilaku yang muncul karena adanya penggugah. Inilah yang dimaksudkan dengan pengondisian operan (operant conditioning) (Boeree, 2005), yang dicetuskan oleh BF. Skinner, salah satu teoretikus kalangan behavioris dalam dunia pembelajaran.

Skinner membedakan tingkah laku responden, yaitu tingkah laku yang ditimbulkan oleh stimulus yang jelas. Misalnya, kucing berlari kesana-kemari karena melihat daging. Karena itulah, perilaku operan adalah tingkah laku yang ditimbulkan oleh stimulus yang belum diketahui, namun semata-mata ditimbulkan oleh organisme itu sendiri, dan belum tentu dikehendaki oleh stimulus dari luar. Misalnya, kucing berlari kesanakemari karena kucing itu lapar, bukan karena melihat daging (Rumini, 1993).

Dalam pengondisian operan, menurut Skinner, hal yang paling dipentingkan adalah respons. Menurutnya, ada dua prinsip umum dalam kondisi ini, yaitu: pertama, setiap respons yang diikuti stimulus yang memberkuat reward (imbalan), akan cenderung diulangi. Kedua, stimulus yang memperkuat imbalan akan meningkatkan kecepatan terjadinya respons operan. Dengan kata lain, imbalan akan mengakibatkan diulanginya suatu respons (Suwarno, 2006).

Pada dasarnya Skinner mendefinisikan belajar sebagai proses perubahan perilaku. Perubahan perilaku yang dicapai sebagai hasil belajar tersebut melalui proses penguatan perilaku yang muncul, yang biasanya disebut dengan pengondisian operan.

Perilaku, seperti respons dan tindakan, adalah sebuah kata yang secara sederhana menunjukkan apa yang diperbuat seseorang untuk situasi tertentu. Secara konseptual, menurut Skinner, perilaku dapat dianalogikan dengan sebuah sandwich, yang membawa dua pengaruh lingkungan terhadap perilaku. Pertama, apa yang disebut dengan anteseden (peristiwa yang mendahului perilaku), dan kedua, apa yang disebut konsekuen (peristiwa yang mengikuti perilaku). Hubungan ini dapat ditunjukkan secara sederhana sebagai Antecedents-Behaviour-Consequences (ABC). Sebagai sebuah rangkaian, perilaku adalah sebuah proses dari Consequences yang diberikan pada pada perilaku akan menjadi Antecedents bagi munculnya perilaku, dan begitu seterusnya. Penelitian dalam pengondisian operan menunjukkan bahwa perilaku operan dapat diubah dengan mengubah anteseden, konsekuen, atau di antara keduanya (Baharudin, 2007).

Setelah melakukan berbagai eksperimen secara berulang-ulang, Skinner berkesimpulan bahwa pada awalnya dalam jangka pendek, baik hukuman maupun imbalan, mempunyai efek mengubah dan menaikkan tingkah laku yang dikehendaki. Namun, dalam jangka panjang, imbalan tetap berefek menaikkan, sedangkan hukuman justru tidak berfungsi. Artinya, antara imbalan dan hukuman tidak simetris (Suwarno, 2006).

Dengan teori ini, dalam menanamkan kejujuran, pemberian hadiah atau hukuman tertentu akan memberikan efek yang signifikan pada awalnya Jika diberikan hadiah, anak akan mengeluarkan respon dengan berperilaku jujur. Tentu saja pemberian hadiah akan terus memberikan efek dalam jangka panjang, jika pemberian hadiah tersebut terus diberikan. Jadi, efek pemberian imbalan atau hukuman ini tentu saja tidak akan membuat kejujuran akan menjadi tertanam dengan baik, karena ada imbalan yang menjadi pemicunya.

Dari pemahaman ini, itu berarti itu pengondisian operan ini akan terjadi dalam dua kondisi: Pertama, siswa harus membuat respon, yaitu siswa harus melakukan sesuatu. Kaum behavioris yakin bahwa hanya sedikit yang dapat dicapai para siswa jika hanya duduk diam dan mendengarkan guru dengan pasif. Sebaliknya siswa akan belajar lebih banyak ketika mereka membuat respons yang aktif dan jelas di kelas. Kedua, penguat harus berdekatan (kontingensi) dengan respon pembelajar, yaitu penguat seharusnya terjadi ketika dan hanya ketika respon yang diinginkan telah terjadi. Guru dalam hal ini seharusnya memberikan penguatan pada perilaku-perilaku yang diinginkan untuk dimiliki para siswa (Ormrod, 2009). 
Jika kita ingin siswa berperilaku jujur, guru seharusnya memberikan penguatan pada perilakuperilaku jujur siswa ketika perilaku-perilaku jujur tersebut muncul. Pada saat yang sama, guru seharusnya berhati-hati untuk tidak memberikan penguatan pada perilaku-perilaku tidak jujur yang ditampilkan siswa. Jika guru secara berulang membiarkan Roni mencuri, dan sering mengijinkan Desy curang ketika bermain, maka guru berarti memberikan penguatan dan bahkan meningkatkan perilaku tidak Jujur Roni dan Desy.

3. Teori Pembelajaran Sosial (Social Learning) Albert Bandura

Banyak perubahan perilaku terjadi disebabkan karena hasil dari pengamatan/observasi terhadap orang lain. Teori kognitif sosial menyatakan bahwa para siswa tidak harus 'bereksperimen' secara trial and error, karena siswa dapat menguasai banyak perilaku atau respon baru hanya dengan mengamati perilaku orang lain atau model (learning by observation) (Ormrod, 2009).

Dalam hal ini, belajar adalah proses internal, yang bisa jadi direfleksikan dalam perilaku dan mungkin juga tidak (Learning as an internal process that may or maynot be reflected in behavior). Contohnya adalah anak melihat perilaku tidak jujur dari gurunya. Mungkin pada saat kecil tidak langsung menirukan gurunya untuk berperilaku tidak jujur, tetapi dapat ditunda saat ia remaja sehingga pada akhirnya akan ikut berperilaku tidak jujur.

Menurut bandura, perilaku bisa mengarah pada suatu tujuan tertentu (goal-directed behavior). Contohnya: siswa akan berkata jujur agar disayang gurunya. Selain itu, menurut Bandura, perilaku diatur dan dikontrol oleh dirinya sendiri (self-regulated of behavior), yaitu siswa mau berperilaku jujur atau tidak tergantung pada motivasi masing-masing. Reinforcement dan punishment cenderung berpengaruh tidak langsung terhadap perilaku (Indirect effects of reinforcement and punishment). Dalam hal ini, Bandura menyatakan bahwa orang belajar banyak perilaku melalui peniruan, bahkan tanpa adanya penguat (reinforcement) sekalipun yang diterima (Ormrod, 2009).

Perilaku peniruan atau proses imitasi itu dapat melalui model hidup (live models), yaitu manusia nyata yang diamati melakukan sesuatu, atau juga melalui model simbolik (symbolic models), yaitu karakter nyata atau fiksi yang digambarkan dalam buku, film, TV, dan melalui berbagai media lain (Ormrod, 2009). Misalnya, siswa dapat mempelajari perilaku jujur dengan mempelajari perilaku tokoh terkenal dalam sejarah atau mengenai orang-orang yang telah meraih hal-hal besar, seperti Albert Einstein, Muhammad Hatta, dan lain sebagainya.

\section{MEMAHAMI KARAKTER, KEJUJURAN, DAN ANAK}

Dalam UU Pendidikan Nasional No. 20 Tahun 2003 pada Pasal 3 dinyatakan bahwa:

"Pendidikan nasional berfungsi mengembangkan kemampuan dan membentuk watak serta peradaban bangsa yang bermartabat dalam rangka mencerdaskan kehidupan bangsa, bertujuan untuk berkembangnya potensi peserta didik agar menjadi manusia yang beriman dan bertakwa kepada Tuhan Yang Maha Esa, berakhlak mulia, sehat, berilmu, cakap, kreatif, mandiri, dan menjadi warga negara yang demokratis serta bertanggung jawab” (Depdiknas, 2003).

Dari kutipan di atas dengan jelas menyatakan bahwa akhlak mulia merupakan aspek penting dalam mendidik anak. Bahkan suatu bangsa yang berkarakter juga ditentukan oleh tingkat akhlak bangsanya. Selain itu, Pasal 3 ini juga menyatakan tentang pembentukan watak dan ini tentu merupakan sebuah upaya untuk membentuk karakter (Hidayatullah, 2010). Hal inilah yang seharusnya diperhatikan bagi dunia pendidikan.

Secara harfiah karakter merupakan kualitas mental atau moral, kekuatan moral, nama atau reputasi (Hornby, 1972), dan ini jelas merupakan nilai-nilai universal yang harus digali dan diperjuangkan oleh setiap individu untuk bisa meningkatkan kualitas kehidupannya ke arah yang lebih baik. Dengan demikian, karakter merupakan ciri dasar melalui mana pribadi itu memiliki keterarahan ke depan dalam membentuk dirinya secara penuh sebagai manusia dengan apa pun pengalaman psikologis yang dimilikinya (Koesoema, 2010).

Menurut Hermawan Kertajaya, karakter adalah ciri khas yang dimiliki oleh suatu benda atau 
individu. Ciri khas tersebut adalah asli dan mengakar pada kepribadian benda atau individu tersebut, dan merupakan mesin yang mendorong bagaimana seseorang bertindak, bersikap, berujar, dan merespon sesuatu.

Ciri khas inilah yang diingat oleh orang lain dan menentukan suka atau tidak sukanya mereka terhadap individu tersebut (Kertajaya, 2010). Dengan demikian, karakter menjadi sebuah evaluasi terhadap kualitas moral individu. Ia bisa juga menyatakan sebuah ragam atribut termasuk eksistensi kekurangan kebajikan seperti integritas, keberanian, keuletan, kejujuran, dan loyalitas, atau perilaku atau kebiasaan baik. Ketika seseorang mempunyai karakter moral, maka itu utamanya merujuk pada kumpulan kualitas yang membedakan satu individu dengan individu lainnya.

Istilah karakter dipakai secara khusus dalam konteks pendidikan baru muncul pada akhir abad keI8. Terminologi ini biasanya mengacu pada sebuah pendekatan idealis-spiritualis dalam pendidikan yang juga dikenal dengan teori pendidikan normatif. Yang menjadi prioritas adalah nilai-nilai transenden yang dipercaya sebagai motor penggerak sejarah, baik bagi individu maupun bagi sebuah perubahan sosial (Koesoema, 2010).

Karakter adalah sebuah kata yang berasal dari bahasa Latin yang artinya "dipahat" (Rutland, 20I0). Namun, berbeda dengan hal itu, kata karakter juga berasal dari bahasa Yunani "Karasso" yang berti "cetak biru", "format dasar", "sidik" seperti dalam sidik jari (Koesoema, 2010).

Dari pengertian secara bahasa ini, kita bisa mengambil pemahaman bahwa karakter itu bisa merupakan sesuatu yang telah tercetak atau bisa juga yang masih berada dalam proses cetak. Hal yang sudah tercetak ini merupakan aspek genetika dan juga pemberian dari Allah Swt., sedangkan yang masih dalam proses adalah sesuatu yang harus diusahakan dan salah satunya adalah dengan pendidikan baik itu formal maupun informal, terutama diterapkan kepada anak.

Anak adalah anak yang masih berada dalam proses pembentukan dan pematangan karakter, sehingga akan sangat tepat jika penanaman karakter dan sifat yang baik itu dilakukan pada anak.

Salah satu karakter baik yang harus ditanamkan kepada anak didik adalah kejujuran. Kejujuran adalah perilaku yang didasarkan pada upaya menjadikan dirinya sebagai orang yang selalu dapat dipercaya dalam perkataan, tindakan, dan pekerjaan.

Jujur dalam Bahasa Arab mengandung arti benar (siddiq). Benar makananya adalah benar dalam perkataan dan benar dalam perbuatan (Yácub, I983). Berlaku jujur dengan perkataan dan perbuatan mengandung makna bahwa dalam berkata harus sesuai dengan yang sesungguhnya, dan sebaliknya jangan berkata yang tidak sesuai dengan yang sesungguhnya.

Perkatan itu sendiri disesuaikan dengan tingkah laku perbuatan. Rasa saling percaya itu hanya tercipta karena ada kejujuran di antara masing-masing pihak. Sebaliknya, perbuatan bohong akan menimbulkan rasa saling membenci antara sesama teman.

Rasa saling mempercayai antar sesama akan hilang, dan akan tercipta suatu bentuk masyarakat yang tidak berlandaskan asas saling tolong-menolong atau gotong royong. Apabila bohong sudah merajalela ke dalam tubuh masyarakat, hilanglah rasa senang dan keakraban antara anggota-anggotanya.

Mengingat dampaknya yang sangat negatif dan membahayakan masyarakat, Islam melarang berbohong dan menganggap perbuatan ini sebagai perbuatan dosa besar. Allah Swt. menegaskan:

"Sesungguhnya Allah tidak memberi petunjuk kepada orang-orang yang melampaui batas lagi pendusta.” (QS. Al-Mu'min: 28)

Dalam firman yang lain, Allah menyatakan:

"Kemudian marilah kita bermubahalah (bersumpah) kepada Allah dan kita minta supaya laknat Allah ditimpakan kepada orang-orang yang dusta" (QS. Ali Imran [3]: 6I).

Bahkan kejujuran ini menjadi salah satu syarat menjadi orang yang bertakwa, dan hal ini bisa dilihat dalam firman Allah Swt.:

"Hai orang-orang yang beriman, bertakwalah kepada Allah, dan

hendaklah kamu bersama orang-orang yang benar" (QS. At-Taubah [9]:

I19). Juga ditegaskan oleh Allah SWT dalam ayat berikut: "Sesungguhnya yang mengada-adakan kebohongan, hanyalah orang- 
orang yang tidak beriman kepada ayat-ayat Allah, dan mereka itulah orang-orang pendusta.” (QS. An-Nahl: I05).

Karena begitu pentingnya kejujuran ini, Rasulullah juga memberikan keteladanan akan sifat kejujuran ini. Bahkan Rasulullah sendiri adalah sosok orang yang dapat dipercaya sehingga mendapatkan gelar al-amin atau orang yang dapat dipercaya.

Dalam hal ini, Rasulullah Saw. Bersabda:

Dari Ibnu Mas'ud r.a., Nabi Saw. bersabda: "Sesungguhnya Kejujuran itu menunjukkan kepada kebaikan dan sesungguhnya kebaikan itu menunjukkan ke syurga dan sesungguhnya seseorang selalu berbuat jujur sehingga dicatatlah di sisi Allah sebagai seorang yang jujur. Dan sesungguhnya dusta itu menunjukkan kepada Kejahatan dan sesungguhnya Kejahatan itu menunjukkan kepada neraka dan sesungguhnya seseorang yang selalu berdusta maka dicatatlah di sisi Allah sebagai seorang yang pendusta” (Muttafaq 'alaih) (Al-Asqalani, I997).

Dari Abu Muhammad Al Hasan Bin Ali r.a., ia berkata bahwa aku menghafal hadits dari Nabi Saw., yaitu: "Tinggalkanlah olehmu apa saja yang kamu ragukan dan beralihlah kepada yang tidak kamu ragukan, sesungguhnya kejujuran itu ketenangan dan kedustaan itu kebimbangan.” (HR.Tirmidzi)

Dari Abu Sufyan bin Shakhr bin Harb r.a. dalam sebuah hadis yang panjang dalam menguraikan ceritera Raja Heraclius. Heraclius berkata: "Maka apakah yang diperintah olehnya?" Yang dimaksud ialah oleh Nabi Saw.

"Pertanda orang yang munafik itu ada tiga: apabila berbicara bohong, apabila berjanji mengingkari janjinya, dan apabila dipercaya berbuat khianat" (HR Bukhari dan Muslim)

Dari beberapa hadist di atas, bersikap jujur dalam segala hal akan membawa manfaat dan kebaikan yang besar dalam kehidupan. Secara psikologis, orang jujur tidak akan terbebani oleh perasaan bersalah kepada dirinya sendiri, juga tidak menentang nuraninya. Sebaliknya kebohongan akan sangat mengganggu suasana hati pelakunya, karena biasanya satu kebohongan memerlukan kebohongan-kebohongan lain untuk menutupinya.

D. PERAN ORANG TUA DAN GURU DALAM PENANAMAN KARAKTER JUJUR PADA ANAK

Peran orangtua dan guru adalah hal yang sangat penting dalam proses penanaman karakter jujur pada anak. Orangtua adalah pendidik yang paling utama di dalam lingkungan rumah tangga, sedangkan guru adalah pendidik formal yang akan menanamkan karakter jujur tersebut di sekolah.

Kolaborasi dan kesinambungan pendidikan di antara keduanya akan sangat penting artinya bagi pengembangan karakter baik pada diri anak didik itu sendiri. Kesadaran akan hal inilah yang harus diperbaiki terlebih dahulu agar terjadi keselarasan dalam pola pendidikannya. Karena itu, peran komite sekolah yang akan menjembatani antara sekolah dengan orangtua akan menjadi vital.

Menurut Kepmendiknas Nomor 044/U/2002, Komite Sekolah adalah badan mandiri yang mewadahi peran serta masyarakat dalam rangka meningkatkan mutu, pemerataan, dan efisiensi pengelolaan pendidikan di satuan pendidikan, baik pada pendidikan pra sekolah, jalur pendidikan sekolah maupun jalur pendidikan di luar sekolah.

Dengan demikian, dalam ranah perundangundangan di Indonesia, komite sekolah merupakan salah satu dari bentuk peran serta masyarakat dalam meningkatkan mutu pelayanan pendidikan yang meliputi perencanaan, pengawasan, dan evaluasi program pendidikan.

Dalam menjalankan tugasnya ini, komite sekolah dibantu oleh dewan pendidikan. Berdasarkan Kepmendiknas No. 044/U/2002 tersebut, tujuan dibentuknya Komite Sekolah adalah sebagai berikut: pertama, mewadahi dan menyalurkan aspirasi dan prakarsa masyarakat dalam melahirkan kebijakan operasional dan program pendidikan di satuan pendidikan; kedua, meningkatkan tanggung jawab dan peran serta masyarakat dalam penyelenggaraan pendidikan di satuan pendidikan; ketiga, menciptakan suasana dan kondisi transparan, akuntabel, dan demokratis dalam penyelenggaraan dan pelayanan 
pendidikan yang bermutu di satuan pendidikan.

Adapun peran Komite Sekolah bisa dijabarkan sebagai berikut: pertama, pemberi pertimbangan (advisory agency) dalam penentuan dan pelaksanan kebijakan pendidikan di satuan pendidikan; kedua, agen pendukung (supporting agency), baik yang berwujud finansial, pemikiran, maupun tenaga dalam penyelenggaraan pendidikan di satuan pendidikan; ketiga, agen pengontrol (controlling agency) dalam rangka transparansi dan akuntabilitas penyelenggaraan dan keluaran pendidikan di satuan pendidikan; dan keempat, agen mediator antara pemerintah (eksekutif) dengan masyarakat di satuan pendidikan.

Dengan tugas dan fungsi tersebut, komite sekolah berarti menjadi jembatan penghubung antara orangtua/masyarakat dengan sekolah. Komunikasi di antara kedua komponen pendidikan ini sangatlah penting sehingga akan memberi dampak yang signifikan terhadap pendidikan anak didik. Jalinan komunikasi inilah yang kemudian akan memaksimalkan peran di antara keduanya, yaitu peran orangtua dan guru dalam mendidik para anak didik.

\section{Peran Guru dalam Penanaman Karakter Jujur bagi Anak}

Sebagai pendidik yang memiliki wewenang penuh dalam mendidik anak di sekolah, guru harus mempunyai kompetensi yang memadai terlebih dahulu. Hal ini penting mengingat kompetensi guru yang baik akan memberikan dampak yang positif bagi pendidikan anak didik. Dengan berkompetensi, guru mempunyai rasa percaya diri dan kemampuan untuk bisa memberikan pendidikan yang efektif dan efisien di dalam kelas. Guru juga akan memiliki keteladanan yang memadai agar bisa digugu dan ditiru oleh anak didik.

Agar bisa menjadi profesional, seorang guru harus mempunyai kompetensi sebagai guru profesional. Dalam hal ini, menurut Undang-Undang No. I4 Tahun 2005 tentang Guru dan Dosen Pasal I0 Ayat (I), dinyatakan bahwa kompetensi guru itu meliputi kompetensi pedagogik, kompetensi kepribadian, kompetensi sosial, dan kompetensi profesional yang diperoleh melalui pendidikan profesi. a. Kompetensi Pedagogik

Dalam Undang-undang No. I4 Tahun 2005 tentang Guru dan Dosen dikemukakan kompetensi pedagogik adalah "Kemampuan mengelola pembelajaran peserta didik". Depdiknas menyebut kompetensi ini dengan "kompetensi pengelolaan pembelajaran. Kompetensi ini dapat dilihat dari kemampuan merencanakan program belajar mengajar, kemampuan melaksanakan interaksi atau mengelola proses belajar mengajar, dan kemampuan melakukan penilaian.

b. Kompetensi Kepribadian

Guru sebagai tenaga pendidik yang tugas utamanya mengajar, memiliki karakteristik kepribadian yang sangat berpengaruh terhadap keberhasilan pengembangan sumber daya manusia. Kepribadian yang mantap dari sosok seorang guru akan memberikan teladan yang baik terhadap anak didik, sehingga guru akan tampil sebagai sosok yang patut "digugu" (ditaati nasehat/ucapan/perintahnya) dan "ditiru" (dicontoh sikap dan perilakunya). Kepribadian guru merupakan faktor terpenting bagi keberhasilan belajar anak didik.

Dalam hal ini, Zakiah Darajat menegaskan bahwa kepribadian itulah yang akan menentukan apakah ia menjadi pendidik dan pembina yang baik bagi anak didiknya, ataukah akan menjadi perusak atau penghancur bagi masa depan anak didiknya terutama bagi anak didik yang masih kecil (tingkat dasar) dan mereka yang sedang mengalami kegoncangan jiwa (tingkat menengah) (Syah, 2000).

\section{c. Kompetensi Profesional}

Menurut Undang-undang No. I4 Tahun 2005 tentang Guru dan Dosen, kompetensi profesional adalah "kemampuan penguasaan materi pelajaran secara luas dan mendalam”. Dalam hal ini, Muhammad Surya mengemukakan bahwa kompetensi profesional adalah berbagai kemampuan yang diperlukan agar dapat mewujudkan dirinya sebagai guru profesional (Surya, 20I3). Kompetensi profesional meliputi kepakaran atau keahlian dalam bidangnya, yaitu penguasaan bahan yang harus diajarkannya beserta metodenya, rasa tanggung jawab akan tugasnya, dan rasa kebersamaan dengan sejawat guru lainnya. 


\section{d. Kompetensi Sosial}

Menurut Undang-undang Guru dan

Dosen, kompetensi sosial adalah kemampuan guru berkomunikasi dan berinteraksi secara efektif dan efisien dengan peserta didik, sesama guru, orangtua/ wali anak didik, dan masyarakat sekitar. Dalam hal ini, Muhammad Surya mengemukakan kompetensi sosial adalah kemampuan yang diperlukan oleh seseorang agar berhasil dalam berhubungan dengan orang lain (Surya, 2013). Dalam kompetensi sosial ini termasuk keterampilan dalam interaksi sosial dan melaksanakan tanggung jawab sosial.

Dengan keempat kompetensi tersebut, guru akan mampu memfungsikan perannya secara maksimal di dalam kelas dan akan mampu menjadikan dirinya sebagai guru profesional yang sejati. Keempat kompetensi ini menggambarkan kapasitas komplet guru, yang meliputi aspek kemampuan keilmuan, aspek kematangan sosial, dan juga aspek kematangan kepribadian.

Mengingat dalam kajian ini adalah berkaitan dengan penanaman karakter jujur, maka keempat kompetensi tersebut sangatlah vital. Guru harus mempunyai kepribadian yang baik, terutama harus menanamkan kejujuran kepada dirinya sendiri, sehingga nantinya aspek keteladanan ini akan ditiru oleh anak didik. Dengan demikian, kompetensi kepribadian merupakan hal yang sangat vital untuk dimiliki dan dimatangkan oleh guru, agar nantinya pada saat diterapkan kepada anak didik akan mampu dilaksanakan dengan baikoleh anak didik.

Dengan memiliki keempat kompetensi di atas, guru diharapkan dapat memberikan pendidikan dan bimbingan yang memadai kepada anak didik. Untuk itu, ada beberapa hal potensi yang harus dimiliki dan diperhatikan, yaitu: pertama, guru wajib peduli terhadap kebutuhan dan problem yang dihadapi siswanya; kedua, guru adalah insan pertama yang mengetahui masalah adaptasi yang dihadapi siswanya; ketiga, guru mengontrol kondisi yang dapat mempengaruhi perkembangan siswa; keempat, guru mempunyai kesempatan untuk mengimplementasikan program hasil konsultasi siswa dengan penyuluh; kelima, guru mempunyai peluang untuk melakukan terapi kelompok; keenam, guru memiliki peluang untuk memberikan pelayanan yang berkorelasi dengan problem dan kebutuhan siswa; ketujuh, guru mempunyai peluang untuk mendapatkan informasi tentang siswa dan potensinya; kedelapan, guru menjalin komunikasi dengan orang tua siswa dan pranata masyarakat; kesembilan, guru mempunyai kedekatan dengan siswa untuk memudahkan guru dalam berkomunikasi dengan siswa (Purnama, 2006).

Dengan sembilan potensi tersebut, pada akhirnya guru mempunyai kesempatan dan potensi yang baik untuk memberikan penanaman karakter jujur kepada anak didik. Untuk bisa mengarah ke sana, ada beberapa hal yang harus dilakukan guru, yaitu (Yusuf, 1989):

Pertama, guru dapat menjadi teladan untuk siswa dalam berperilaku, bertutur kata dan beragama.

Kedua, guru seyogyanya mengerti dan menghargai keunikan siswa baik kelebihan maupun kekurangannya, pendapatnya, tidak mencemoohnya, memberikan reward dan pujian yang memadai atas prestasi yang dicapai siswanya.

Ketiga, guru membimbing siswanya dengan cara menciptakan suasana kelas yang rileks dan mampu menstimulasi perkembangan siswa, menginformasikan cara belajar efektif, melakukan sosialisasi peraturan sekolah agar dapat dipahami oleh siswa manfaat dan tujuannya, menciptakan budaya belajar dan karakter yang baik

Dalam proses penanaman karakter jujur kepada anak didik, langkah-langkah yang bisa dilakukan guru adalah sebagai berikut: Pertama, mengimplementasikan pembiasaan sikap dan perilaku jujur di sekolah. Untuk menumbuhkan sikap dan perilaku jujur, tidak cukup hanya dibekali pengetahuan dan cerita tentang kejujuran, tetapi dibutuhkan pembiasaan sikap dan perilaku sehari-hari sehingga muncul refleks dalam berperilaku jujur.

Mendidik karakter adalah menanamkan nilai kepada siswa. Untuk menanamkan nilai, tidak cukup hanya melalui ranah kognitif, tetapi harus sampai pada ranah afektif dan psikomotorik. Karena nilai atau values adalah berada pada ranah afektif, bukan pada ranah kognitif. Tetapi untuk sampai pada ranah afektif, harus melalui ranah kognitif terlebih dahulu 
yaitu berupa penjelasan dan pengetahuan tentang kejujuran. Selanjutnya diikuti dengan organizing values dan internalizing values.

Kedua, memberikan kesadaran dan keyakinan bahwa Tuhan Maha Melihat. Jelaskan pada anak bahwa apapun yang kita lakukan, dimanapun berada, Tuhan akan selalu melihat dan mencatat seluruh perilaku kita walaupun manusia tidak melihatnya.

Ketiga, Menyadarkan anak bahwa kejujuran itu lebih nikmat daripada kebohongan. Karena kejujuran dapat menghantarkan pada kedamaian, kenyamanan, ketenangan dan kebahagiaan hidup.

Dengan ketiga hal tersebut, paling tidak proses penanaman karakter jujur itu akan bisa dilaksanakan. Tapi hal ini tentu harus dimulai dari guru itu sendiri yang harus memiliki empat kompetensi guru sehingga akan memberikan keteladanan yang baik pada anak didik.

Selain itu, guru awalnya bisa memberikan stimulan dengan cara memberikan hadiah atau penghargaan tertentu kepada anak yang sudah berlaku jujur. Hal ini tentu sesuai dengan teori pengondisian operan yang dicetuskan B.F. Skinner. Namun, pemberian hadiah atau penghargaan itu tidak boleh terus dilakukan, karena akan menanamkan pada pikiran anak didik bahwa kejujuran itu bisa dibeli atau dikompensasi dengan hadiah atau penghargaan. Hal ini tentu memberikan preseden buruk nantinya. Karena itu, teori pembelajaran dengan mengedepankan reward and punishment seperti yang diberikan oleh Kohlberg tentu saja harus dibatasi, dan tidak boleh diberikan terus-menerus, tapi hanya sebagai stimulan saja seperti apa yang dinyatakan Skinner.

Selain itu, teori pembelajaran sosial juga sangat penting, dan hal ini tentu terkait dengan tingkat kompetensi guru, khususnya kompetensi kepribadian guru, yang akan memberikan keteladanan terhadap anak didiknya. Pada dasarnya, guru adalah sosok yang patut untuk ditiru dan digugu oleh anak didiknya, sehingga guru menjadi model pembelajaran yang akan terusmenerus diamati anak didik dalam proses pembelajaran di sekolah. Karena itulah, jika guru tidak memiliki empat kompetensi menjadi guru profesional, tentu saja akan memberikan dampak yang tidak baik bagi proses penanaman karakter yang baik pada anak didik.
2. Peran Orang Tua dalam Penanaman Karakter Jujur bagi Anak

Peran orangtua dalam penanaman karakter jujur pada anak ini lebih banyak kepada bagaimana memberikan pengertian dan pemahaman kepada anak tentang pentingnya kejujuran dalam kehidupan. Tentu saja hal ini harus diteladankan oleh orangtua untuk selalu berlaku jujur di hadapan anak-anak, terutama pada anak yang masih dalam usia dini. Pada usia ini, anak sering kali meniru apa yang ada di lingkungannya, terutama orangtuanya. Jika orangtua berlaku jujur, anak tentu akan meniru orangtuanya. Begitu juga sebaliknya, anak akan meniru ketidakjujuran orangtua saat orangtua berlaku tidak jujur kepada anaknya atau kepada orang lain yang dilihat dan didengar anaknya.

Dalam hal ini, ada beberapa hal yang bisa dijalankan orangtua yang bisa menggambarkan peran orangtua dalam penanaman karakter jujur kepada anaknya. Pertama, tumbuhkan kesadaran bahwa berbohong adalah hal yang sangat berbahaya. Jelaskan secara detail dan berikan contoh konkret dalam kehidupan sehari-hari yang dapat dilihat dan dipahami anak. Kedua, jangan sungkan untuk meminta maaf pada anak kalau kebetulan orang tua berbuat salah, lupa dengan janji yang telah dibuat, dan sebagainya. Ketiga, jawab pertanyaan anak dengan benar sesuai dengan tahapan usia perkembangannya. Apapun yang ingin ditanyakan anak menunjukkan bahwa sudah saatnya anak mengetahui berbagai hal. Tinggal kemampuan orang tua menjelaskan dengan kalimat yang dimengerti oleh anakanak. Keempat, berikan perhatian yang cukup pada anak. Perhatian dan pengawasan memiliki peranan penting dalam membentuk kepribadian anak. Tentu saja tanpa membuat anak merasa selalu dimata-matai oleh orang tuanya. Kelima, orangtua bisa membacakan buku yang menceritakan perilaku jujur, kemudian mendiskusikan pemahaman tentang jujur, mengapa harus jujur, contoh perilaku jujur dan tidak jujur, bagaimana jika ada teman yang tidak jujur? Keenam, menerapkan sikap jujur saat bermain, belajar, berinteraksi dengan orang tua, guru, teman, saudara, dan sebagainya dengan cara menghargai sikap jujur anak yang ditunjukkan anak dengan cara menguatkan melalui kalimat, misalnya: "terima kasih kamu sudah jujur." 
Itulah beberapa peran dan langkah yang bisa dipraktikkan orangtua dalam menanamkan karakter jujur kepada anaknya. Yang paling penting dalam hal ini adalah bagaimana menanamkan kejujuran tersebut sebagai sebuah pengetahuan yang baik pada anak, sehingga hal ini akan memunculkan kesadaran akan pentingnya bersikap jujur tersebut dalam kehidupan sehari-hari. Karena itulah, pada prosesnya ini harus dilakukan dengan cara-cara yang menyenangkan dan suasana yang aman dan nyaman.

Dari penjelasan di atas, peran guru dan orangtua memang sangat penting dalam proses penanaman karakter jujur pada anak. Pada prosesnya, guru dan orangtua bisa melakukan penanaman nilai-nilai sikap jujur tersebut. Setiap nilai sikap yang telah dimasukkan ke dalam rencana pembelajaran harus diterapkan secara berkelanjutan. Penanaman nilai sikap terus diterapkan dalam bentuk pembiasaan yang direncanakan secara matang oleh satuan Pendidikan Anak (PAUD). Sikap yang diterapkan dimasukkan dalam Rencana Pelaksanaan Pembelajaran Harian (RPPH) atau dalam Standar Operating Procedure (SOP) harian dari pagi hingga anak pulang sekolah.

Yang paling penting adalah guru harus menjadi model yang baik untuk anak, sehingga anak dapat mencontoh perilaku jujur melalui perilaku guru. Selain itu juga guru dapat menampilkan kisah atau dongeng atau film yang menceritakan tentang manfaat dan manisnya kejujuran, agar anak dapat memahami dan meniru bahwa perilaku jujur itu menyenangkan dan banyak manfaatnya, di antaranya disayang teman, guru, orang tua dan orang-orang di sekitar. Selain itu juga dengan berperilaku jujur, seseorang akan banyak teman, dipercaya dan dihormati serta dihargai.

Anak didik adalah makhluk yang memiliki kreatifitas dan serba aktif yang menuntut agar dalam pendidikan anak benar-benar dibimbing dan diarahkan agar ia dengan sendirinya juga menampakkan kreatifitasnya. Di dalam proses belajar mengajar anak harus diperhatikan dan diposisikan sesuai dengan kemampuannya, serta pendidikan hendaknya lebih bersifat menolong berkembangnya pikiran kritis, tidak hanya berupa pemberian materi pelajaran yang tidak memenuhi kepada apa yang dibutuhkan anak. Karena itulah, kreativitas itu harus diarahkan ke arah yang positif dan baik, terutama terkait dengan penanaman kepribadian yang baik, seperti berlaku jujur dalam kehidupan sehari-hari.

Karena itulah, guru harus proaktif terhadap hal ini. Guru harus segera mengingatkan dan memperbaiki jika ada perilaku yang tidak jujur di kelas, seperti: ketika anak bermain curang, berkata bohong, meminjam tanpa minta ijin, mencuri, tidak mau mengakui kesalahan dan tidak mau meminta maaf, dan sebagainya. Selain itu, pemberian hukuman bisa diberikan pada anak yang berbuat kesalahan. Namun pemberian hukuman merupakan pilihan yang paling akhir dan diberikan mulai dari yang paling ringan. Hukuman bisa diberikan jika anak telah memahami konsep baik buruk dengan benar.

\section{E. PENUTUP}

Penanaman karakter jujur pada anak itu sangat penting dilakukan untuk bisa membentuk masa depan generasi penerus bangsa yang jujur dan tidak berperilaku menyimpang dalam kehidupan dirinya sendiri maupun dalam kehidupan berbangsa dan bernegara. Karena itulah, peran guru dan orangtua dalam menanamkan karakter jujur ini sangat penting.

Agar bisa efektif dan efisien, guru harus memiliki empat kompetensi agar bisa memberikan keteladanan yang baik kepada anak didik. Sedangkan orangtua juga harus memiliki pemahaman dan pengetahuan yang memadai serta kepribadian yang baik agar bisa memberikan keteladanan kepada anak, terutama terkait dengan masalah kejujuran. Ada banyak langkah yang bisa dijalankan, dan yang paling penting adalah bagaimana menanamkan kesadaran yang utuh kepada anak agar menjadikan kejujuran sebagai sebuah hal yang positif bagi kehidupannya, sehingga anak mampu memiliki pemahaman akan perbedaan karakter baik dan buruk serta apa konsekuensinya dalam kehidupan.

\section{DAFTAR PUSTAKA}

Al-Akk, Syekh Khalid bin Abdurrahman, 2006, Cara Islam Mendidik Anak, Yogyakarta: Ad-Dawa'

al-Asqalani, Ibn Hajar, 1997, Bulughul 
Maram, Penerj. Machfuddin Aladif, Semarang: Toha Putra

Baharudin dan Esa Nur Wahyuni, 2007, Teori Belajar dan Pembelajaran, Yogyakarta: Ar-Ruzz Media

Baqi, Muhammad Fu'ad 'Abdul, tth, Al-Mu'jam al-

Mufahras li al-Faz al-Quran al-Karim, Juz. I, Indonesia: Maktabah Dahlani

Barnadib, Imam, 1988, Dasar-Dasar Pendidikan Perbandingan, Yogyakarta: Institut Press, IKIP Yogyakarta

Boeree, C. George, 2005, Sejarah Psikologi: Dari Masa

Kelahiran sampai Masa Modern, Penerj. Abdul Qodir Shaleh, Yogyakarta: Prismasophie

Depdiknas, 2003, Undang-Undang No. 20 Tahun 2003 tentang Sistem Pendidikan Nasional (Sisdiknas)

Beserta Penjelasannya, Yogyakarta: Media Wacana Dewantara, Ki Hajar, 1977, Bagian Pertama Pendidikan, Yogyakarta: MLTS

Driyarkara, I980, Driyarkara Tentang Pendidikan, Yogyakarta: Yayasan Kanisius

Hidayatullah, M. Furqon, 20I0, Pendidikan Karakter: Membangun Peradaban Bangsa, Surakarta: UNS Press

Hornby, A.S., dan E.C. Parnwell, 1972, Learner's Dictionary, Kuala Lumpur: Oxford University Press

Kepmendiknas nomor 044/U/2002.

Kertajaya, Hermawan, 2010, Grow With Character: The

Model Marketing, Jakarta: Gramedia Pustaka Utama

Koesoema A., Doni, 20I0, Pendidikan Karakter: Strategi Mendidik Anak di Zaman Global, Jakarta: Grasindo

Lampiran Kepmendiknas nomor: 044/U/2002.

Ormrod, Jeanne Ellis, 2009, Psikologi pendidikan, Jilid I, Jakarta: Erlangga

Purnama, Diana Septi, 2006, Upaya Guru dalam Mengembangkan Disiplin Belajar Siswa, dalam Jurnal Paradigma, No. OI Th. I, Januari

Rumini, Sri, I993, Psikologi Pendidikan, Yogyakarta: UPP IKIP Yogyakarta

Rutland, Mark, 2009, Karakter itu Penting, Penerj. Ly Yen, Jakarta: Light Publishing

Slavin, Robert E., 2009, Psikologi Pendidikan: Teori dan Praktik, Edisi kesembilan, Jilid I, Jakarta: PT Indeks

Suparno, Paul, 200I, Pendidikan Demokrasi, Yogyakarta: Sanata Dharma Press

Surya, Muhammad, 2003, Psikologi Pembelajaran dan Pengajaran, Bandung: Yayasan Bhakti Winaya Suwarno, Wiji, 2006, Dasar-Dasar Ilmu Pendidikan, Yogyakarta: Ar-Ruzz Media

Syah, Muhibbin, 2000, Psikologi Pendidikan dengan Pendekatan Baru, Bandung: PT Remaja Rosdakarya

Ya’cub, Hamzah, I983, Etika Islam, Bandung: Diponegoro

Yusuf LN, Syamsu, 1989, Disiplin Diri dalam Belajar Dihubungkan dengan Penanaman Disiplin yang Dilakukan Orang Tua dan Guru," Tesis, FPS IKIP Bandung 